\title{
OVATKO KORKEAKOULUT JA YLIOPISTOT AHDISTUSKONEITA?
}

Kollegani, metriikka-asiantuntija Eva Isaksson kannusti lukemaan ajatushautomo Higher Education Policy -instituutin raportin Pressure Vessels: The Epidemic of Poor Mental Health Among Higher Education Staff. Raportti on karua kieltä brittiläisestä korkeakoulujärjestelmästä, erityisesti sen opiskelijoiden ja työntekijöiden hyvinvoinnista - tai oikeastaan pahoinvoinnista.

Vuosina 2009-2016 on nähty suuri kasvu työterveys- ja työpsykologikäynneissä: joissain yliopistoissa lisääntynyt tarve on voinut olla jopa yli kolminkertainen. Vuoden 2012 rahoitusmallin muutoksen jälkeen kasvussa tapahtui jyrkkä käänne ylöspäin. Työstä johtuvat mielenterveyden ongelmat ovat korkeakoulusektorilla yleisempiä kuin poliiseilla tai terveydenhuollossa työskentelevillä.

Ammattiliitot ovat huolissaan akateemisesta, palkattomasta ylityöstä: Nottinghamin yliopistossa $74 \%$ kertoi tekevänsä vähintään kuusi tuntia ja $29 \%$ yli I I tuntia ylitöitä viikossa.

Akateemisesta työstä on tullut suuri "ahmimiskilpailu, jossa palkintona hyvin tehdystä työstä on lisää ahmittavaa”. Kun suuri tutkimustyö on valmis, voi pitää vapaata ja juhlia yhden iltapäivän, sillä seuraavana aamuna on aloitettava uusi.

Yliopistoja ja korkeakouluja onkin alettu kutsua nimellä anxiety machine, ahdistusta tuottava kone tai ahdistuskone. Syitä tähän ovat raportin

kirjoittaneen Liz Morrishin mukaan seuraavat asiat:

- Liiallinen työmäärä, jota on mahdotonta saada valmiiksi työajalla.

- Jatkuva arviointi, erityisesti kansallinen auditointi ja metriikka, kuten tutkimuksen ja opetuksen arviointi ja pyrkimys pärjätä niissä.

- Työsopimusten lyhyys ja määräaikaisuus, pätkä- ja silpputyö. Uran suunnittelu tai eteneminen on näissä oloissa vaikeaa tai mahdotonta.

- Suorituksen mittaaminen sidotaan lyhyen tähtäimen tavoitteisiin, joihin monen on vaikeaa yltää työn luonteen vuoksi.

Morrish suosittelee, että tilanteen parantamiseksi työtaakkoja on kevennettävä ja tutkijan uraa ja etenemistä tuettava. On ymmärrettävä, että akateemiselle työlle pitkän tähtäimen tavoitteet ovat tärkeitä ja mittaamisen eli metriikan on oltava nykyistä vastuullisempaa.

Vastuullista tutkijan arviointia on alettu peräänkuuluttaa laajasti 2o Io-luvulla. Vuonna 2015 Metric Tide -raportti julisti, että metriikalla on valtaa, jota ei pidä käyttää kevyesti ja huolimattomasti. Suomeksikin saatavilla

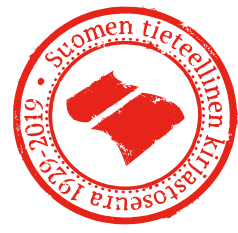


olevat Leidenin manifesti ja DORA-julistus ovat inspiroineet monia vastuullisen arvioinnin aloitteita, myös meillä Suomessa. Tieteellisten seuran valtuuskunnan koordinoima ryhmä tekee suositusta tutkijan vastuullisesta arvioinnista ja Laura Himanen vetää Vastuullinen metriikka -työryhmää, joka valmistelee kansallista linjausta metriikan vastuullisesta tuottamisesta ja hyödyntämisestä. Tänä vuonna Julkaisufoorumi on päivittänyt luokituksen käyttöohjeita ja Helsingissä julkaistiin Tieteellisen viestinnän mo- nikielisyyden Helsinki-aloite.

Yksi tärkeä vaikutuskanava omaan ja akateemisten instituutioiden hyvinvointiin sekä kehittymiseen ovat seurat, kuten STKs ja Informaatiotutkimuksen yhdistys ITY ry. Tänä syksynä seurojen toimintaa mahdollistava Tieteellisten seurain valtuuskunta juhlii I 20-vuotispäiväänsä muun muassa \#SiksiTieteellinenSeura -kampanjalla. Olethan jo huomannut, miten 90 vuotta täyttävä STKS tarjoaa syksyllä monia ajankohtaisia seminaareja? Tervetuloa mukaan!

Johanna Lahikainen

\section{Lähteet}

DORA-julistus: https://sfdora.org/read/fi/

Grove, JACK, 2019, "Union says 'intolerable' workloads driving rise in staff sickness". Times Higher Education. https://www.timeshighereducation.com/news/union-saysintolerable-workloads-driving-rise-staff-sickness (Luettu I 8.9.2019)

Leidenin manifesti: http://www.leidenmanifesto.org/translations.html

MAYO, NiCK, 20I9, "University staff' at breaking point' as counselling demand soars". Times Higher Education.

https://www.timeshighereducation.com/news/university-staff-breaking-point-counsellingdemand-soars (Luettu I8.9.2019).

Morrish, Liz, 20I9, Pressure Vessels: The epidemic of poor mental health among higher education staff. HEPI Occasional Paper, 20.

https://www.hepi.ac.uk/wp-content/uploads/20 I 9/05/HePr-Pressure-Vessels-OccasionalPaper-20.pdf

(Luettu 17.9.2019)

Szetela, Adam, 201 8, "Feeling Anxious? You're Not the Only One". The Chronicle of Higher Education. https://www.chronicle.com/article/Feeling-Anxious-You-reNot/243 I I7 (Luettu I 8.9.2019)

Wilsdon, J., et al. (2015). The Metric Tide: Report of the Independent Review of the Role of Metrics in Research Assessment and Management. DOI: IO.I 3 I 4O/RG.2.I.4929.I 363 